Stutterheim E \& Weyers $M L$

\title{
STRENGTHS-FOCUSED INTERVENTION: THE NEW APPROACH OF THE SOCIAL WORK SERVICE OF THE SOUTH AFRICAN POLICE SERVICE
} (SAPS)

Dr Erika Stutterheim is the Director of Social Work Services of the South African Police Service (SAPS) and Prof Mike Weyers is a Lecturer at the School for Psychosocial Behavioural Sciences: Social Work Division, Potchefstroom University for CHE.

\section{INTRODUCTION}

In 1996 social work in the newly constituted South African Police Service (SAPS) was at a crossroad. The era of the South African Police (SAP) had ended with the promulgation of the South African Police Service Act (Act 68/1995) on 4 October 1995. The South African Police Service (SAPS) was in the process of implementing a new policy that emphasised the empowerment of personnel in the interests of effective service delivery within a transforming organisation and society. At the same time however, SAPS was facing an increase in the incidence of social problems among its 120000 members. A choice had to be made. It was either to stick to the therapy-centred approach that had become the norm in the SAP, or try to conceptualise an alternative service-delivery paradigm. The choice fell on the latter. The result was the operationalised version of social work's strengths approach that now forms the basis of occupational social work in the SAPS.

In describing the development, nature and implications of the strengths-focused approach, three themes will be covered. They are, firstly, the historical factors that compelled Police Social Work Services (PSWS) to opt for this new approach; secondly, the nature and practical implications of the approach; and, thirdly, the implications that the approach will have for the organisation and South African occupational social work in general.

\section{SOCIAL WORK IN THE SAP: 1952-1995}

The historical factors that necessitated the development of a new approach can be divided into two broad categories. These are the factors that came out of the era of the South African Police (SAP) (1952-1995) and those that pertain to the growth of the South African Police Service (SAPS) (1995 to present). In both cases the history will be divided into phases according to their most significant events (Ackerman, 1987; Ackerman, 2002; Dippenaar, 1988:244, 295, 429; Marais, 1988:15-20; Schoeman, 1996:50-56; Stutterheim \& Weyers, 2002; Van der Merwe, 1985:10-26).

\section{The pre-social work phase: $1952-1969$}

The roots of social work services in the Police Service can be traced back to 1952, when Rev. HP Martin was approached to deal with the spiritual needs and social problems of members of the then South African Police (SAP). Although not an appointed chaplain, he held church services in the SAP on a contractual basis.

In 1960 the first full-time chaplain, Rev. MDV Cloete, was appointed. Because one of his main tasks was to establish a chaplains' corps, the number of chaplains steadily increased in the following years. Although they focused mainly on spiritual needs and religious matters, they also dealt with police members' social problems (Dippenaar, 1988:244, 295). 


\section{The phase of the "welfare officers": 1969-1979}

By 1969 social problems among SAP members had taken on an immensity that rendered the chaplains' services insufficient. Consequently, on 10 September 1969 the Minister of Police gave authorisation for the chaplains' services to be supplemented with the services of welfare officers. Dippenaar (1988:478) described the circumstances in which this step took place as follows: "Purely practical considerations soon forced Police authorities to take an entirely new approach and appoint professional persons... The first people thus appointed were welfare officials".

However, the first "welfare officials" could not be described as "professionals" in the true sense of the word. It was rather decided that they would be recruited from the ranks of the SAP. The reasoning behind this step was that they would be familiar with, amongst other things, the structure, culture and activities of the organisation. The candidates for these posts had to have at least nine to 12 years of service in the SAP, had to hold the rank of a warrant officer or lieutenant and had to be willing to undergo a three-month course on welfare-related issues. The first welfare officers joined the Chaplain Service on 1 August 1971.

It soon became apparent that the welfare officers were unable to live up to the tasks they were required to perform (Ackerman, 2002). It was therefore decided to start employing fully trained social workers. (Coincidentally, this followed soon after the appointment of the first members of the so-called "Female Police Force" in 1971/1972 (Dippenaar, 1988:429).) The handful of qualified social workers who joined the SAP during this period were still required to undergo the basic police training course of six months.

\section{The transitional phase: 1979-1990}

In 1979 the Public Service Commission approved the establishment of a social work division in the SAP. This step gave social workers professional status in the organisation. Under this new dispensation 29 posts for social workers were created nationwide.

However, in terms of Special Force Order 13A of 1980 (SAP, 1980), the services rendered by the social workers were still viewed as an extension of and supplementary to the chaplains' services. By implication, in terms of the command structure of the SAP Head Office, the Social Work Services section still fell under the direct control and leadership of the Chief Chaplain.

In 1988 an inquiry was ordered into the separation of the social work and the chaplains components. The outcome of this inquiry was that, at the end of 1990, the Commissioner of the SAP ordered that a separate and autonomous occupational group be created for social workers.

\section{The structural repositioning phase: $1991-1995$}

Social work started to function as an autonomous section within Human Resources Management on 1 January 1991. It was their task to deliver a professional social work service to all police personnel.

In 1992 a decision was taken to demilitarise the sections of the SAP that did not perform functional police work. On 25 January 1993 the first civilian social workers were appointed in the South African Police. Consequently, two groups of social workers, namely those with functional ranks and those without functional ranks, were then employed by the organisation. The former were appointed in terms of the Police Act and the latter in terms of the Public Service Act. This untenable situation changed at the end of 1996 when all social workers were appointed in terms of the South African Police Service Act (SA, 1995). 
From an analysis of the history of social work in the Police Service up to 1995 three significant trends emerged:

- The first was that the establishment of an independent social work service within the organisation was a long and somewhat arduous process. This could, however, be expected in an occupational social work setting where an ancillary service is rendered within an organisation whose core business differs from that of social work. This difficulty was compounded by the tendency of members of armed forces to mistrust occupational groups they viewed as "outsiders" (Mocke, 1991:93);

- Secondly, social workers were continually compelled to prove to both management and employees that their services were to the benefit of the organisation and its individual members;

- The third trend was that social workers focused their services almost exclusively on individual employees and their social problems. This was required from the first social workers who were appointed in the 1970s and it became part of the legacy on which the service was built up to 1995.

\section{SOCIAL WORK IN THE SAPS AND THE DEVELOPMENT OF THE STRENGTHS-FOCUSED APPROACH: 1995 TO PRESENT}

By 1996 the newly instituted South African Police Service (SAPS) was investigating the feasibility of outsourcing various services. Police Social Work Services was one of the sections that were under real threat of such a step because of , amongst others things, its perceived lack of cost effectiveness. What followed was a remarkable turnaround of events that culminated in 2002 in the allocation of 203 new posts for social workers to PSWS by the National Commissioner. This step made the SAPS one of the bigger employers of social workers in South Africa.

The way that this turnabout occurred will be described in more detail below.

\section{The need for change}

The choice of the strengths-focused approach in police social work was not necessarily a conscious decision that was taken at a specific point in time. It was, rather, the result of a process of responding to changes in the needs and nature of the organisation, in the environment in which it operated and in social work itself.

The need for and the beginnings of the change in approach can be traced back to the early 1990s when social workers structurally became an autonomous occupational group in the organisation. Changes in South Africa's political system before and directly after 1994, however, stifled any real movement in a new direction. PSWS was therefore somewhat ill-equipped to respond quickly to the new South African Police Service's emphasis on the empowerment of its members to deliver effective service in the context of a transforming organisation and society (SAPS Bulletin, 2000:1).

The need for change was not driven by organisational and external factors only. By 1996 it became clear to the social workers themselves that the growing incidence of personal and workrelated problems in the police workforce could no longer be dealt with by therapy-centred and reactive intervention alone. An alternative would have to be found. 


\section{The impetus: Ask Africa's baseline research into the service needs of SAPS personnel}

In response to changes in the organisation and the needs of police members, a research consultant, Ask Africa, was contracted to conduct extensive research into (a) SAPS members' needs regarding social work services; (b) the social workers' views of the personnel's needs, and (c) a comparison of these two sets of perceptions. Ask Africa produced their final report in 1998 (Ask Africa, 1998).

On the basis of the research report the management of PSWS concluded that there was still a need for therapeutic services. What also became clear, however, was that the development of some form of proactive and empowerment-centred service should also receive a high-priority rating. This paved the way for the paradigm shift to the strengths-focused approach.

\section{The turning point: the National Conference for Police Social Workers}

A national conference for all social workers in the employ of the SAPS was held in September 1999. There was widespread support for the idea of the development and implementation of proactive services and that these services should take on the form of personnel capacity-building programmes (PCBPs).

In terms of the decisions reached at the conference:

- Police Social Work Service would develop, standardise, register and implement personnel capacity building programmes (PCBPs) as a form of proactive service; and

- $\quad$ these programmes would initially focus on stress management, substance dependence, general life skills, colleague sensitivity, financial difficulties and HIV/AIDS awareness.

With the above resolutions PSWS inadvertently introduced strengths-focused intervention as an approach in service delivery. At that time, however, the "strengths tag" was not formally attached to the decision.

\section{The beginning of the operationalisation process: the development and implementa- tion of personnel capacity-building programmes (PCBPs)}

The operationalisation of the strengths-focused approach began with the development of the personnel capacity-building programmes (PCBPs). In March 2000 working groups were established to develop the identified PCBPs. The groups had one content expert for each programme in every province. Work on the initial programmes was completed in August 2000. The working groups came up with the following programmes:

- Managing stress effectively

- Substance dependence

- Life skills (consisting of nine sub-programmes)

- Colleague sensitivity

- Be money wise, and

- HIV/AIDS prevention and awareness (PSWS, 2002).

It is at this stage necessary to take a closer look at the nature and verification of these programmes. 


\section{The basic nature of the programmes}

The PCBPs are aimed at the development of the five categories of competencies that make up the profile of a resilient person (see Table 1). They were based on available literature and the so-called best practices of individual social workers in the SAPS. This proved to be a winning recipe. It not only resulted in an extensive package of standardised, high-quality programmes, but also a package that was in tune with the unique nature and needs of the organisation and its employees.

TABLE 1

A PROFILE OF THE PERSONNEL CAPACITY-BUILDING PROGRAMMES

\begin{tabular}{|c|c|c|c|c|c|}
\hline COMPETENCIES $\rightarrow$ & 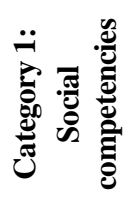 & 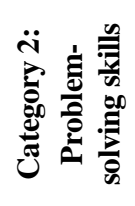 & 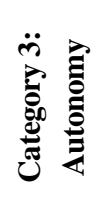 & 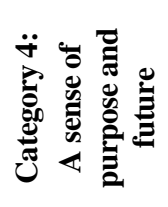 & 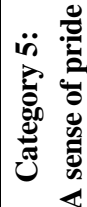 \\
\hline - Colleague Sensitivity & $\mathrm{x}$ & $\mathrm{x}$ & $\mathrm{x}$ & $\mathrm{x}$ & $\mathrm{x}$ \\
\hline - $\quad$ How to Manage Stress Effectively & $\mathrm{x}$ & $\mathrm{x}$ & $\mathrm{x}$ & $\mathrm{x}$ & $\mathrm{x}$ \\
\hline - $\quad$ Be Money Wise & $\mathrm{x}$ & $\mathrm{x}$ & $\mathrm{x}$ & $\mathrm{x}$ & $\mathrm{x}$ \\
\hline - $\quad$ Substance Dependence & $\mathrm{x}$ & $\mathrm{x}$ & $\mathrm{x}$ & $\mathrm{x}$ & $\mathrm{x}$ \\
\hline - $\quad$ HIV/AIDS Awareness & $\mathrm{x}$ & $\mathrm{x}$ & $\mathrm{x}$ & $\mathrm{x}$ & $\mathrm{x}$ \\
\hline \multicolumn{6}{|l|}{ - $\quad$ Life Skills } \\
\hline - Healthy lifestyle & $\mathrm{X}$ & $\mathrm{x}$ & $\mathrm{X}$ & $\mathrm{X}$ & $\mathrm{X}$ \\
\hline - Conflict management & $\mathrm{X}$ & $\mathrm{X}$ & $\mathrm{X}$ & $\mathrm{X}$ & $\mathrm{X}$ \\
\hline - Communication & $\mathrm{x}$ & $\mathrm{x}$ & $\mathrm{x}$ & $\mathrm{x}$ & $\mathrm{x}$ \\
\hline - Self-knowledge & $\mathrm{x}$ & $\mathrm{x}$ & $\mathrm{x}$ & $\mathrm{x}$ & $\mathrm{x}$ \\
\hline - Assertiveness & $\mathrm{X}$ & $\mathrm{X}$ & $\mathrm{x}$ & $\mathrm{x}$ & $\mathrm{x}$ \\
\hline - Problem solving & $\mathrm{x}$ & $\mathrm{x}$ & $\mathrm{x}$ & $\mathrm{x}$ & $\mathrm{x}$ \\
\hline - Time management & $\mathrm{x}$ & $\mathrm{x}$ & $\mathrm{X}$ & $\mathrm{x}$ & $\mathrm{X}$ \\
\hline - Motivation & $\mathrm{x}$ & $\mathrm{x}$ & $\mathrm{x}$ & $\mathrm{x}$ & $\mathrm{x}$ \\
\hline - Planning of goals & $\mathrm{X}$ & $\mathrm{x}$ & $\mathrm{x}$ & $\mathrm{x}$ & $\mathrm{X}$ \\
\hline
\end{tabular}

Social competencies: These include the qualities of responsiveness, flexibility, empathy and caring, communication skills, a sense of humour and any other form of constructive social behaviour.

Problem-solving skills: These include the ability to think abstractly, reflectively, the ability to be flexible and the ability to seek alternative solutions for both cognitive and social problems.

Autonomy: This refers to a strong sense of independence, an internal locus of control, a sense of power, and self-esteem and self-efficacy.

A sense of purpose and future: This refers to healthy expectations, a positive goal and success orientation, the will to be successful, educational aspirations, persistence, optimism, hopefulness, hardiness, belief in a bright future, a sense of anticipation, a sense of a compelling future and a sense of coherence. 
A sense of pride: Pride helps people to overcome obstacles and rebound from misfortune and hardship. It can also take the form of survivor's pride.

Currently each programme consists of prescribed learning material, workbooks and handouts for participants, and a comprehensive presenter's guide and presentation plan. As a package, therefore, it contains all the material and teaching tools required for the task.

The programmes are presented in a workshop format in order to maximise group participation and, as far as possible, to meet individual needs. The time allocated to the presentation varies from programme to programme. In most instances the programmes are presented separately. However, the sub-programmes that make up the general life skills programme are often combined in various ways.

The programmes are usually presented on request to different sections and stations, but in some instances they are presented as a result of an organisational analysis. Some of the programmes, for example, the HIV/AIDS Awareness Programme, form an integral part of service delivery.

\section{The verification of the programmes}

After the initial programmes had been developed, they were piloted in both urban and rural areas among all races and both genders. The results obtained were used to bring about mostly minor adjustments to their contents and method of presentation. Representatives from each province were then trained in the implementation of the final programmes. They were expected to use the "train the trainers" method to teach all the other social workers to do the same. Up to the present the programmes have been presented to more than 4000 employees.

Although each programme contained basic evaluation instruments, the need soon arose for a more comprehensive assessment of the impact and of the quality of the presentation. This was needed to ensure that the programmes would meet the goals and represent a cost-effective type of intervention. A decision was therefore taken in 2001 to launch a comprehensive impact assessment and cost-benefit study into the programmes. This study, which has become known as the Evaluation of Personnel Capacity-Building Programmes (EPCBP) Project, is being conducted under the auspices of the Potchefstroom University for CHE.

Currently two PhD and seven MA (Social Work) students are working on the research project. A comparison group pretest-posttest design is being used to ascertain what impact the programmes have on participants' level of knowledge, attitudes and skills. The PhD students will also do a cost-benefit analysis of the programmes once the results of the impact analyses become known.

The research project is extremely comprehensive. It is envisaged that, in total:

- thirty one new measuring instruments will be designed during the process;

- the views of more than 3000 participants will be tested;

- more than 15000 individual questionnaires will be completed; and

- more than 225000 individual measurements will be made, excluding the pilot studies.

At present the research is at the pilot study stage. It has, however, already shown very promising results. There are strong indications that each of the proactive programmes has a strong positive impact on the resilience of Police personnel.

During the development, implementation and verification of the PCBPs great strides were made with the conceptualisation of the strengths approach as it would apply to the SAPS. The results that have thus far been achieved in this regard will consequently be discussed. 


\section{THE NATURE OF POLICE SOCIAL WORK SERVICE'S STRENGTHS- FOCUSED APPROACH}

According to Van Wormer, Wells \& Boes (2000:178), the strengths approach had been a traditional perspective in the field of social work, but one that has only quite recently been reclaimed. In terms of this approach everything that the social worker does is predicated on the principle of helping the client system to discover, embellish, explore and exploit their strengths and resources in the process of assisting them to achieve their goals, realise their dreams and shed the chains of their own inhibitions, misgivings and self-perceived weaknesses (Saleebey, 1997:18). This approach thus requires that all forms of professional intervention - whether of a therapeutic of proactive nature - should focus on strengths. This goal has as yet not been accomplished in the SAPS. It must, for example, still be accepted by all Police social workers and also permeate through to the clinical facet of the services. For this reason we can only talk about a focus on strengths at this stage and not a fully-fledged strengths approach.

\section{The general nature of strengths}

Miley, O’Melia and DuBois (2001:448) define strengths as “...personal abilities, resourcefulness, and creativity, as well as resources in interpersonal relationships, culture, organisational networks, and community connections", while McAuaide and Ehrenreich (in Miley et al., 2001:205) is of the opinion that strengths are relative and "...cannot be isolated from the situation in which they are expressed". Their relativity makes the categorisation and listing of strengths an extremely difficult task. The following six categories of strengths, however, appear in most such lists (Miley et al., 2001:209-211; Saleebey, 1996:299-300; Saleebey, 1997:59; Zuns \& Chernesky, 2000:157-170):

- Experience. This refers to everything that people learn about themselves, others and their world as they struggle, cope and battle with abuse, trauma, illness, confusion, oppression and even their own fallibility. People do no learn just from their successes but also from their failures and disappointments, including the self-imposed ones.

- Personal qualities, character traits and virtues. These are sometimes forged in situations of trauma and catastrophe. They might be anything from a sense of humour, creativity, patience, loyalty, insight and independence to spirituality and moral imagination. These qualities and characteristics might become sources of energy and motivation when working with the client system.

- Knowledge of the world. This refers to intellectual knowledge that the person has gained during his or her lifetime through both formal and informal education and training. Individuals often have a vast reservoir of such knowledge that goes untapped.

- Talents. Many people have undiscovered or underdeveloped talents. Playing a musical instrument, telling stories, cooking, home repair, writing, carpentry, etc. may provide additional tools and resources to assist individuals or groups in reaching their goals.

- Culture. Folklore and personal stories can be profound sources of strength, guidance, stability, comfort or transformation. Their importance is often overlooked or minimised, and stories can become distorted over time.

- The community. The community in all its variations, e.g. the neighbourhood, the workplace and the geographical community, is frequently overlooked as a physical, interpersonal and institutional terrain full of resources that can be tapped into. This environment is often a rich 
landscape filled with people and organisations who, when asked, would provide their talents and knowledge to help others.

\section{Main principles on which the strengths-focused approach is built}

There are five principles that should form the cornerstone of all strengths-focused interventions. The basic nature of these principles (Gray \& Collett van Rooyen, 2002:196-199; Kisthardt, 1997:98-90; Lee, 1994:27-28; Saleebey, 1997:12-15) and the way that they impact on service delivery in the SAPS are discussed next.

\section{Principle 1: Every individual, group and community has strengths}

First and foremost the strengths-focused approach is about identifying assets, resources, wisdom and knowledge, respecting these qualities and believing in their potential power. All humans do thus have the inherent capacity to learn, grow and change (Kisthardt, 1997:98; Lee, 1994:27).

All the PCBPs that have been developed are primarily based on this principle. They focus on the identification and enhancement of the strengths that police officers already possess and represent a strong belief in these individuals' ability to learn and to grow under the stimulating influence of others.

\section{Principle 2: Trauma, abuse, illness and struggle may be injurious, but they may also be sources of challenge and opportunity}

The "damaged goods paradigm" has become dominant in the thinking of both the so-called helping professions and the people they serve. This often leads to discouragement, pessimism and a victim mindset (Lee, 1994:27-28) that obscure any strengths or possibilities for recovery.

An organisation such as the SAPS whose employees work in a high-risk, high-stress environment is especially susceptible to a "damaged goods" mindset and the general negativity that accompanies it. To counteract this tendency the proactive service rather focuses on what can be learned from the traumatic or stressful events that are often part of employees' daily routine.

\section{Principle 3: Do not underestimate an individual, group or community's capacity for growth and change}

Too often professionals assume that a diagnosis, an assessment or a profile is the only parameter within which their clients can deal with their particular issues. Thus the diagnosis or assessment becomes a verdict and a sentence. Practitioners must, instead, have high expectations of their clients and align their professional opinions with the client's hopes, visions and values.

This principle in many ways contradicts the dominant view in bureaucratic organisations, where perceived superiority is based on rank. It therefore challenges professionals such as social workers and other members of the helping professions to respect and admire their clients. It is the only way in which the core goal of occupational social work - namely to empower employees to function effectively in the working environment and as individuals - can be reached.

\section{Principle 4: We best serve the client system by collaborating with the client}

Professionals could get so locked into the role of "expert" that they forget the equally important roles of a collaborator and a consultant. The strengths-focused approach, however, is predicated on the idea that change can only come about when the social worker collaborates with the client and takes account of the client's aspirations, perceptions and strengths. 
In practice this implies, among other things, that social workers in the Police Service should perform organisational readings and needs assessments to ensure that they take into account the objectives, perceptions and strengths of both individuals and the organisation as a whole.

\section{Principle 5: Every environment is full of resources}

The entire community should, according to Kisthardt (1997:98), be viewed as an oasis of potential resources that can be enlisted on behalf of consumers. The most important of all these resources are the individual members of these systems. In the SAPS, as with many other systems, all that is really necessary is to enable members to play a more direct and active role in enhancing each other's capacities. This is done by means of group involvement in proactive capacity-building programmes and support groups.

The five principles have various implications for social work in the SAPS. They all boil down to the following statement of intent:

We, as social workers in the SAPS, cannot prevent the traumatic events and experiences that are sometimes part and parcel of police officials' work, but we can change their reactions to such events and their ability to deal with them. This is done by strengthening their resilience through, inter alia, the implementation of proactive programmes as a form of strengths-focused intervention. The development of a resilient police official is, therefore, the basic goal of our service delivery.

The way in which the strengths-focused approach has been operationalised in the SAPS is depicted in Figure 1.

FIGURE 1:

\section{FRAMEWORK OF THE OPERATIONALISATION OF THE STRENGTHS-FOCUSED APPROACH IN THE SAPS}

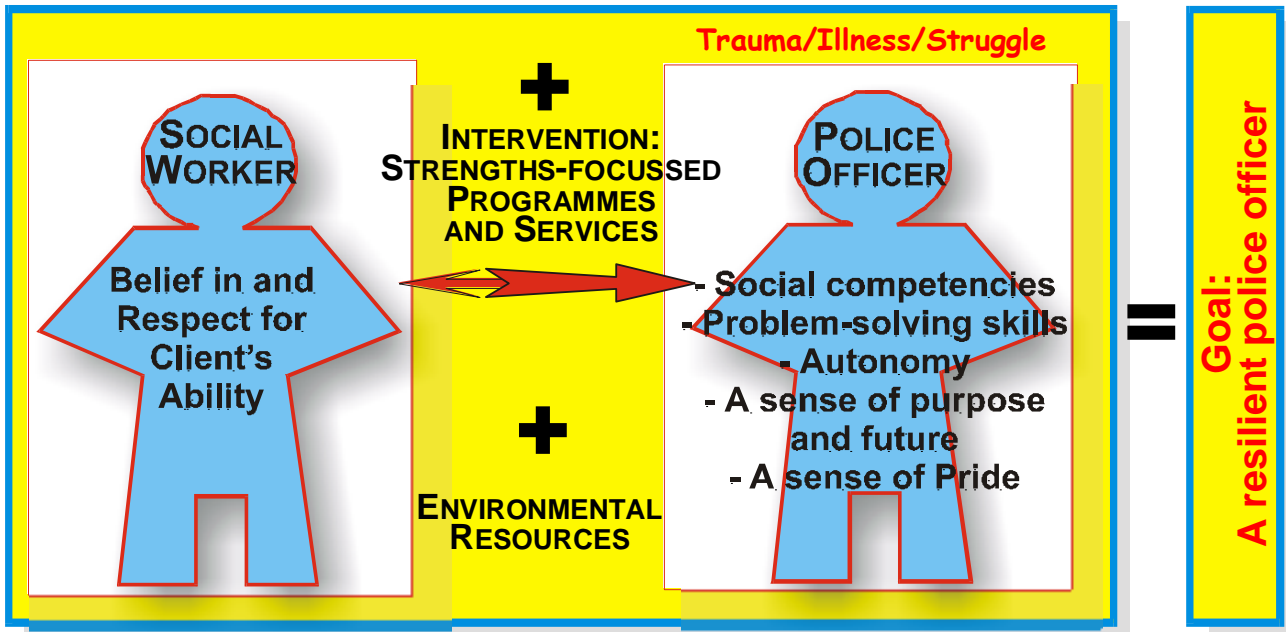

(With acknowledgement to Miley et al., 2001:90-92; DuBois \& Miley, 2002:70-76; Lee, 1994:2728). 


\section{Goal and objectives of strengths-focused intervention}

\section{Resilience as the goal of the strengths-focused intervention}

In order to contextualise the basic goal of the Police Social Work Services' strengths-focused intervention, viz. the development of resilient police officers, it is necessary to define what is meant by the concept "resilience". In the context of police social work it could be defined as:

the process, capacity and outcome of successful adaptation to challenges and adversity, sustained competence under threatening circumstances and the ability to recover from trauma (Kumpfer, 1999:181).

\section{Profile of the resilient person and the objectives of strengths-focused intervention}

In order to achieve the goal of resilient police members, interventions should enhance various capacities, resources, talents, strengths, knowledge and adaptive skills. These competencies can be grouped into five categories that encompass the profile of a resilient person (Kumpfer, 1999:205; Naude, 1999:84-88; Saleebey, 1996:299; Saleebey, 1997:198). The development of these competencies is basically the objective of intervention.

\section{Category 1: Social competencies}

Social competencies include the qualities of responsiveness, flexibility, empathy and caring, communication skills, a sense of humour and any other constructive social behaviour. Resilient people are considerably more responsive and they can obtain more positive responses from others. They are more active, flexible and adaptable. Furthermore, they have the ability to generate comic relief and find alternative ways of looking at things and to laugh at themselves and at ridiculous situations. Consequently, they tend to establish more positive relationships with others, including friendships with their peers. These traits are essential for a police official to function optimally in the SAPS.

\section{Category 2: Problem-solving skills}

These skills include the ability to think abstractly, reflectively and creatively. The individual should also be courageous enough to attempt alternative solutions for cognitive, emotional and social problems.

\section{Category 3: Autonomy}

Different researchers have used different concepts to refer to autonomy. These include a strong sense of independence; an internal locus of control; a sense of power; and self-esteem and selfefficacy. Essentially, it entails having a sense of one's identity, being able to set boundaries, acting independently and exerting some control over one's environment, including the working environment.

Adaptive distancing is another important dimension of autonomy. It basically entails the ability to be involved in a distressful work-related situation without being affected by the suffering, symbolism and negative emotions that accompany it. The ability to use adaptive distancing is an essential skill for police officials, especially those who are exposed to potentially traumatic incidents in the line of duty. They include officials at mortuaries, forensic laboratories, criminal record centres and the photography units, who are continually exposed to gruesome scenes or incidents. 


\section{Category 4: A sense of purpose and future}

A sense of purpose and future is closely linked to a sense of autonomy and self-efficacy, and the belief that one has some measure of control over one's environment. This capability encompasses several characteristics, including:

- healthy expectations

- a positive goal and success orientation

- the will to be successful

- educational aspirations

- persistence

- optimism

- hopefulness

- hardiness

- belief in a bright future

- a sense of anticipation

- a sense of a compelling future, and

- a sense of coherence.

Police members need a sense of coherence, purpose and meaning as well as optimism in order to fight against and to deal with the problems of their daily lives. As an objective in service delivery the development of these abilities stands in direct contrast to the "learned helplessness" that is often the result of the application of other approaches.

\section{Category 5: A sense of pride}

Everyone has some sense of pride and pride can be used to drive the engine of change. Individuals who have rebounded from misfortune and hardship often have so-called "survivor's pride". This self-regard is, however, frequently buried under a heap of self-blame, shame and labelling. Police officials' inherent pride in themselves and in the work they do must be uncovered, fostered and strengthened to enable them to "survive" emotionally.

\section{THE USE OF THE STRENGTHS-FOCUSED APPROACH IN THE ARMED FORCES, OCCUPATIONAL SOCIAL WORK AND BEYOND}

The adoption of the strengths-focused approach by South Africa's Police social workers has already had a profound effect on the way in which services are rendered. There has been a clear move away from purely reactive clinical work in favour of a mixed approach that also incorporates proactive interventions. This broadened the scope of services, increased the number of recipients, reduced the occurrence of social problems, increased the resilience of personnel and thereby benefited the organisation as a whole. It also improved the image of social workers and ultimately proved the worth of social work as a profession. This contributed towards more than doubling of the number of social workers in the employ of the SAPS.

The development and implementation of the proactive personnel capacity-building programmes (PCBPs) has to a large extent been groundbreaking work. This is especially true in the light of Kumpfer's finding that, up until 1999, only a limited number of prevention programmes had been based on resilience theory or were specifically designed to increase resilience (Kumpfer, 1999:180).

Experience has shown that the strengths-focused approach is especially suited and beneficial to the work done by social workers in the armed forces and in occupational social work in general. 
However, the establishment of this operational paradigm would seem to be a difficult task. Early adopters of the approach will have to face the resistance of individual practitioners and professional groups who adhere to a strong problem-focused approach and operate with a fixed mindset of "expert versus patient/clients".

On the basis of the experience gained in the SAPS, the following practical recommendations can be made regarding ways to overcome resistance to such a new approach:

- Firstly, it is necessary for social workers and their employers to do research into the unique combination of social problems and needs of employees; the nature of the demands that the organisation places on the employees; and how employees feel about the services being rendered to them by social workers and or other members of the helping professions;

- Secondly, the results of the baseline research should be used to convince practitioners of the need to change the conventional approach that they have followed. The strengths-focused approach will never gain a foothold unless a significant number of practitioners are convinced of its value;

- When the second task has been successfully completed, the research results could thirdly also be utilised in the process of designing appropriate proactive programmes or other forms of structured service delivery;

- Once completed, the programmes or services should fourthly be aggressively marketed to the whole organisation (i.e. management and workers). There should therefore be a move away from the "response to demands" mindset that is often typical of other approaches to one with a stronger "outreach" focus;

- Lastly, it is of the utmost importance that the impact and cost effectiveness of the programmes be measured scientifically. This will not only ensure their worth, but also provide a basis for the expansion of the strengths-focused approach to other sectors of the organisation and beyond.

\section{CLOSING REMARKS}

The adoption and operationalisation of the strengths-focused approach by local social workers is still in its infancy. However, from the practical experience gained over the past two years in the South African Police Service it has become abundantly clear that it will be the ideal service delivery paradigm for the future. It enlarges the scope of services that can be delivered, makes prevention a functional part of the social worker's core business, increases the status and image of the profession, and helps to counteract the deficits fixation that has characterised local social work thought for a number of years. Through it, the era of "positive social work" may have started for South Africa.

\section{REFERENCES}

ACKERMAN, D.H. 1987. Social work main file, 7/2/1. Pretoria: South Africa Police Service.

ACKERMAN, D.H. 2002. Personal interview with the former Head of Social Work Services of the SAP. Pretoria.

ASK AFRICA. 1998. Social work needs assessment. Pretoria: SAPS.

DIPPENAAR, M. de W. 1988. The history of the South African Police: 1913-1988. Pretoria: Promedia Publications. 
DuBOIS, B. \& MILEY, K.K. 2002. Social work: an empowering profession. Boston: Allyn and Bacon.

GRAY, M. \& COLLET VAN ROOYEN, C.A.J. 2002. The strengths perspective in social work: lessons from practice. Social Work/Maatskaplike Werk, 38(3):193-201.

KISTHARDT, W. 1997. The strengths model of case management: principles and helping functions. In: SALEEBEY, D. (ed) The strengths perspective in social work practice. $\left(2^{\text {nd }}\right.$ ed) New York: Longman Publishers.

KUMPFER, K.L. 1999. Factors and processes contributing to resilience: the resilience framework. In: GRANTS, M.D. \& JOHNSON, J.L. (eds) Resilience and development: Positive life adaptations. New York: Kluwer Academic/Plenum Publishers.

LEE, J.A.B. 1994. The empowerment approach to social work practice. New York: Columbia University Press.

MARAIS, S.G. 1988. Maatskaplike werk in die Suid-Afrikaanse Polisie - faktore wat maatskaplike hulpverlening beïnvloed. Stellenbosch: University of Stellenbosch. (Unpublished dissertation)

MILEY, K.K.; O’MELIA, M. \& DuBOIS, B. 2001. Generalist social work practice: an empowering approach. Boston: Allyn and Bacon.

MOCKE, P. 1991. Empowering the police officer at work. London: B.T. Batsford.

NAUDE, J.L.P. 1999. Psychological strengths and job satisfaction of representatives in the fertiliser industry. Potchefstroom: PU for CHE. (Unpublished MA thesis in the Department of Industrial Psychology)

POLICE SOCIAL WORK SERVICES 2000. Annual report: April 1999 to March 2000. Pretoria: SAPS.

POLICE SOCIAL WORK SERVICES. 2002. Research project: proactive programmes of social work services 7/2/6. Pretoria: SAPS.

PSWS see POLICE SOCIAL WORK SERVICES

SA see SOUTH AFRICA (REPUBLIC)

SALEEBEY, D. 1996. The strengths perspective in social work practice: extensions and cautions in social work. Social Work, 41(3):296-305.

SALEEBEY, D. 1997. The strengths approach to practice. In: SALEEBEY, D. (ed) The strengths perspective in social work practice. $\left(2^{\text {nd }}\right.$ ed) New York: Longman Publishers.

SAP see SOUTH AFRICAN POLICE

SAPS see SOUTH AFRICAN POLICE SERVICE

SCHOEMAN, G.A.M. 1996. Die rol van die maatskaplike werker in die Suid-Afrikaanse Polisiediens. Pretoria: University of South Africa. (Unpublished dissertation)

SOUTH AFRICA (REPUBLIC). 1995. South African Police Service Act, 68/1995. Pretoria: Government Printers.

SOUTH AFRICAN POLICE SERVICE. 2000. SAPS Bulletin: the new strategic focus of the SAPS for 2000 to 2003. Pretoria: SAPS. 
SOUTH AFRICAN POLICE. 1980. Special Force Order 13A/1980. Pretoria: SAP.

STUTTERHEIM, E. \& WEYERS, M.L. 2002. Strengths-focused intervention: the new approach of the social work service of the South African Police Service (SAPS). Paper presented at the: XXXIV International Conference on Military Medicine (ICMM) held at Sun City, South Africa, from 15-20 September, 2002.

VAN DER MERWE, S.L. 1985. Maatskaplikewerk-dienste binne die raamwerk van die SuidAfrikaanse Polisie, met besondere verwysing na die benutting van gemeenskapswerk. Pretoria: University of Pretoria. (Unpublished dissertation)

VAN WORMER, K.; WELLS, J. \& BOES, M. 2000. Social work with lesbians, gays, and bisexuals: A strengths perspective. Boston: Allyn and Bacon.

ZUNS, S.J. \& CHERNESKY, R.H. 2000. The workplace as a protective environment: management strategies. In: NORMAN, E. (ed) Resiliency enhancement: putting the strengths perspective into social work practice. New York: Colombia University Press. 